\title{
Population Dynamics of the Lance Nematode (Hoplolaimus galeatus) in Creeping Bentgrass
}

\author{
D. M. Settle, Department of Plant Pathology, J. D. Fry, Department of Horticulture and Recreation Resources, and
} T. C. Todd and N. A. Tisserat, Department of Plant Pathology, Kansas State University, Manhattan 66506

\begin{abstract}
Settle, D. M., Fry, J. D., Todd, T. C., and Tisserat, N. A. 2006. Population dynamics of the lance nematode (Hoplolaimus galeatus) in creeping bentgrass. Plant Dis. 90:44-50.

The effects of management practices and nematode population density on the seasonal fluctuations in lance nematode (Hoplolaimus galeatus) populations in creeping bentgrass were studied in a naturally infested experimental putting green and in artificially infested microplots. In general, H. galeatus populations increased from late spring through midsummer, declined in August, and increased again in the fall. Population increase in microplots was strongly density dependent, with final population densities inversely proportional to inoculum levels. Ectoparasitic populations of $H$. galeatus in both studies were composed of adults and juveniles, whereas endoparasitic populations were almost exclusively juveniles. H. galeatus populations in the naturally infested site were aggregated spatially, but the aggregation was not temporally stable. Nematode populations were not affected by bentgrass cultivar selection or irrigation frequency.
\end{abstract}

Additional keyword: turfgrass

Numerous species of plant-parasitic nematodes feed on the roots of creeping bentgrass grown for golf course putting greens $\quad(9,13-15,31,32,43,48-51,54,56)$. These nematodes, alone or in various combinations, may contribute to a decline in turf quality during periods of warm soil temperatures that can evoke drought or heat stress $(7,16,21,25,29,33,37,46,50)$. However, conclusive proof of their pathogenicity to this cool-season turfgrass is lacking in most cases and, instead, has been inferred by turfgrass scientists and golf course superintendents based on the negative effects nematodes can have on warm-season turfgrasses in the southern United States.

Nematode populations on putting greens may fluctuate with time. Blackburn et al. (5) found that fluctuations of Hoplolaimus galeatus populations on a velvet creeping bentgrass (Agrostis canina L.) putting green were due to natural reproductive cycles. Davis et al. (14) reported that ring nematode (Criconemella curvata (Raski) Luc and Raski) population densities followed a similar seasonal pattern on all creeping bentgrass greens at the same golf

Corresponding author: N. A. Tisserat

E-mail: Ned.Tisserat@ colostate.edu

Current address of N. A. Tisserat: Department of Bioagricultural Sciences and Pest Management, Colorado State University, Ft. Collins 80523.

Accepted for publication 5 August 2005.

DOI: 10.1094/PD-90-0044

(C) 2006 The American Phytopathological Society course. Lucas et al. (31) observed that $H$. galeatus and stubby root nematode (Paratrichodorus christei (Allen) Siddiqi) populations in a creeping bentgrass putting green peaked in June, declined in August, then increased again through December. They found that low H. galeatus densities in midsummer were associated with reduced creeping bentgrass growth due to high soil and air temperatures. Todd and Tisserat (50) observed that $C$. ornata and $H$. galeatus population densities peaked in midsummer. In contrast, Wick and Vittum (56) found that populations of $H$. galeatus and several other nematode species fluctuated with time, but did not always follow a consistent seasonal trend. Nematode populations on creeping bentgrass greens also may be spatially aggregated. Todd and Tisserat (50) reported that spatial aggregation of $H$. galeatus and $C$. ornata increased through the summer.

The influence of cultural practices on lance nematode population densities in creeping bentgrass is largely unknown. Davis and Dernoeden (13) found that application of activated sewage sledge and poultry waste increased lance nematode populations on a creeping bentgrass putting green compared with several other organic nitrogen sources. This is contrary to reports that indicate that organic $\mathrm{N}$ sources and organic soil amendments are capable of suppressing plant-parasitic nematodes $(10,24,40)$. Walker et al. (55) reported that Hoplolaimus spp. population densities were negatively correlated with soil bulk density. They speculated that water-holding capacity of the soil increased at higher bulk densities and resulted in decreased nematode activity.

The purpose of our research was to monitor spatial and temporal distributions of the lance nematode in naturally and artificially infested creeping bentgrass plots maintained at putting green mowing heights. We also assessed the effects of cultivar, mowing height, and irrigation practices on lance nematode population densities.

\section{MATERIALS AND METHODS}

Microplots. Twenty microplots were established in June 2000 on a sand-based putting green at the Rocky Ford Turfgrass Research Center, Manhattan, KS. The green, which was seeded to A-4 creeping bentgrass at $49 \mathrm{~kg} / \mathrm{ha}$ in fall 1998, had a root zone of $97.5 \%$ sand and $2.5 \%$ clay, with a $\mathrm{pH}$ of 7.5. Microplots were spaced 1 $\mathrm{m}$ apart in a 4-by-5-m area. Each microplot consisted of a 30.5-cm-diameter schedule40 PVC tube (Diamond Plastics Corp, Grand Island, NE) placed into the green to a depth of $38 \mathrm{~cm}$. The PVC tube was installed vertically so that the upper edge of the tube was flush with the putting green surface to permit mowing. Sod within each tube was removed, washed thoroughly to remove adhering sand and soil particles, and stored at $4^{\circ} \mathrm{C}$. Soil mix in each tube was removed, bulked, mixed, and steamed at $80^{\circ} \mathrm{C}$ for $90 \mathrm{~min}$. The mix was aerated by turning the soil by hand daily for 1 week and then placing it back into the microplots. No phytoparasitic nematodes were detected in the steamed mix.

$H$. galeatus inoculum was extracted from 380 liters of naturally infested soil collected from a second bentgrass putting green at the same location using a modified sucrose flotation technique (28). Other phytoparasitic nematodes were present at low populations but were not detected in the final inoculum following extraction. On 6 June 2000, microplots were infested with one of three $H$. galeatus (adults + juveniles) population densities. Individual microplots were infested by pouring $50 \mathrm{ml}$ of nematode-free filtrate (control), or 50 , 100 , and $200 \mathrm{ml}$ of filtrate containing 50 H. galeatus $/ \mathrm{ml}$ of water on the soil surface in the microplots (hereafter referred to as $1 / 2 \times, 1 \times$, and $2 \times$ rates). The washed bentgrass sod then was placed on top of the infested soil. Treatments were arranged in a completely randomized block design with five replications. 
The putting green containing the microplots received $1 \mathrm{~cm}$ of water at $0600 \mathrm{~h}$ three times weekly ( $3 \mathrm{~cm} /$ week) and was clipped at $4.0 \mathrm{~mm}$ height 6 days per week. The green was fertilized with nitrogen at $270 \mathrm{~kg} \mathrm{ha}^{-1}$ in each year. Timing of individual applications varied yearly; however, generally, $\mathrm{N}$ at 25 to $49 \mathrm{~kg} \mathrm{ha}^{-1}$ was applied every 4 weeks between 1 April and 1 October in each year. Brown patch (Rhizoctonia solani) and dollar spot (Sclerotinia homoeocarpa) were controlled with periodic preventive applications of azoxystrobin (Heritage 50 WG; Syngenta Crop Protection Inc, Greensboro, NC) at $0.3 \mathrm{~kg}$ a.i. ha ${ }^{-1}$ and triadimefon (Bayleton $50 \mathrm{DF}$; Bayer Corp, Kansas City, MO) at $0.8 \mathrm{~kg}$ a.i. $\mathrm{ha}^{-1}$, respectively. Insecticides were not used for the duration of the study. Microplots were top dressed with sand periodically to compensate for soil settling.

Putting green. An 8-by-24-m putting green area consisting of four bentgrass cultivars was used to evaluate the effects of mowing and irrigation on nematode populations. The root zone mixture had a sand content of $97.9 \%$, an organic matter content of $2.1 \%$, a pH of 7.3 , and a bulk density of $1.5 \mathrm{~g} \mathrm{~cm}^{-3}$. The green was naturally infested with phytoparasitic nematodes. $H$. galeatus populations dominated but $\mathrm{Cri}$ conemella, Paratrichodorus, Hemicycliophora, and Helicotylenchus spp. also were present in low populations (20 to 90 per $100 \mathrm{~g}$ of dry soil).

Treatments were arranged in a stripstrip-strip plot design with three replications. Main plots consisted of two 4-by-8$\mathrm{m}$ irrigation strips. The entire green was irrigated with $1 \mathrm{~cm}$ of water at $0600 \mathrm{~h}$ three times weekly ( $3 \mathrm{~cm} /$ week) using an automated irrigation system. One of the irrigation strips received supplemental hand watering $(0.5 \mathrm{~cm} /$ day $) 6$ days per week at $1400 \mathrm{~h}$ for a total irrigation of 6.0 $\mathrm{cm} /$ week. Subplots were four 2-by-8-m

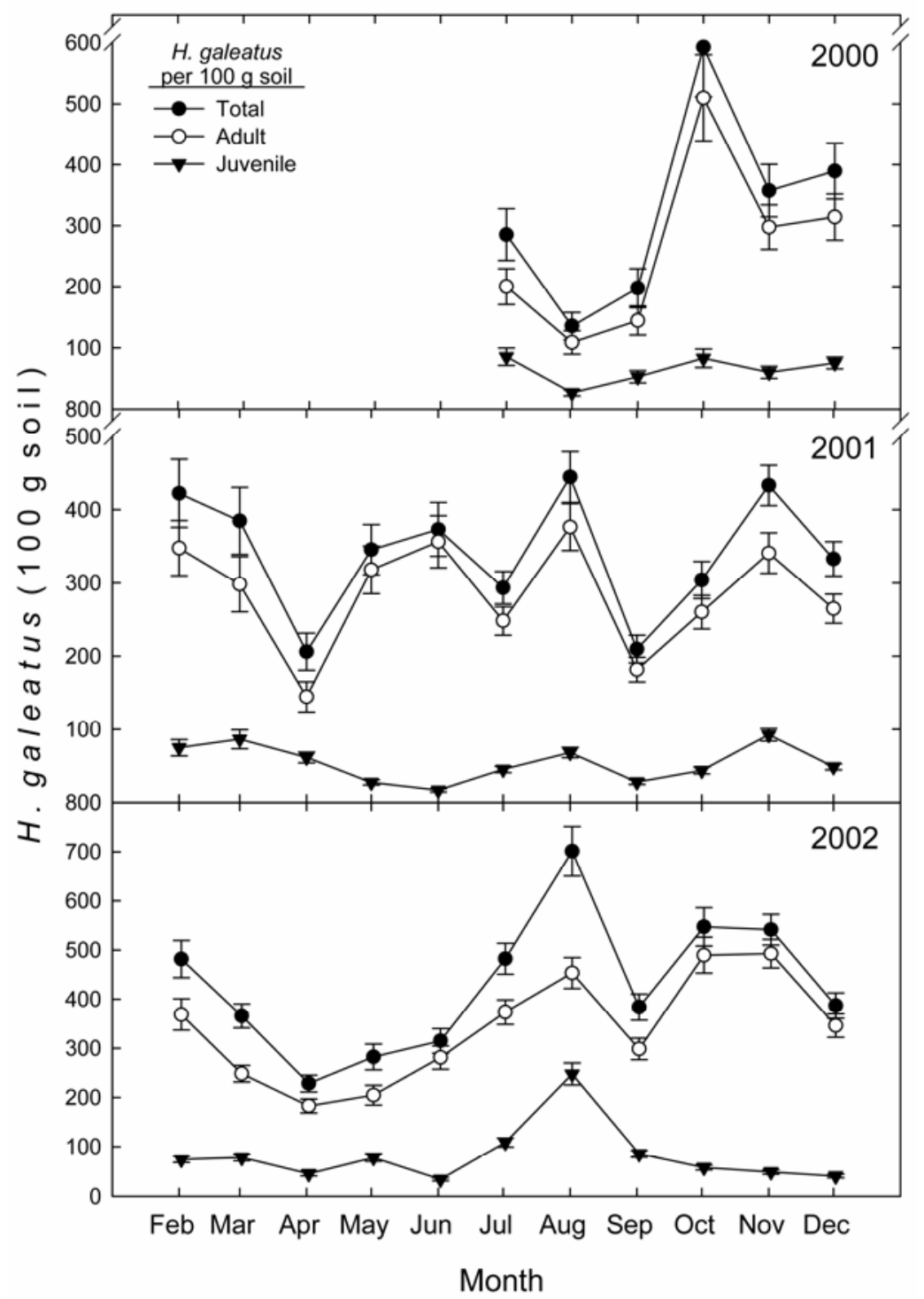

Fig. 1. Seasonal fluctuations of Hoplolaimus galeatus juvenile, adult, and total populations per $100 \mathrm{~g}$ of soil in a creeping bentgrass putting green during 2000 to 2002. Monthly averages are from 96 (48 in 2000) sample sites from four creeping bentgrass cultivars. Bars represent standard errors.

bentgrass cultivar strips of Penncross, Crenshaw, L-93, or Providence that were seeded in May 1996 at $49 \mathrm{~kg} \mathrm{ha}^{-1}$. Cultivar subplots were split into two 1-by-8-m subsubplots that were mowed at 3.2 or $4.0 \mathrm{~mm}$ 6 days per week. The entire green was mowed 6 days per week to a height of 4.0 $\mathrm{mm}$ with a triplex greensmower. Subsubplots requiring the $3.2-\mathrm{mm}$ clipping height were mowed again with a walkbehind greensmower.

Nematode extraction. $H$. galeatus populations in field microplots were determined approximately every month from July 2001 to October 2003 by systematically collecting (clockwise progression) two soil cores $2 \mathrm{~cm}$ in diameter by $13.5 \mathrm{~cm}$ deep. Core holes were filled with sand. Bulked, mixed soil (75 g) was processed for nematodes. Nematodes were extracted using a modified sucrose flotation technique (28). Each soil sample was placed in a 3.8-liter beaker that was filled with water to suspend soil and sand particles. The suspension was poured immediately through two nested sieves $(850-\mu \mathrm{m}$ to capture plant debris and $38-\mu \mathrm{m}$ to capture nematodes). Washings that consisted of nematodes and the organic fraction of the soil were collected and the procedure was repeated. Contents of the $38-\mu \mathrm{m}$ sieve were centrifuged for $1 \mathrm{~min}$ at $183 \mathrm{rad} \mathrm{s}^{-1}$ without braking. Water was decanted and the remaining soil pellet was resuspended in $40 \mathrm{ml}$ of a $45 \%$ sucrose solution. The sucrose suspension was centrifuged for $1 \mathrm{~min}$ at $183 \mathrm{rad} \mathrm{s}^{-1}$ and the supernatant was decanted onto a $25-\mu \mathrm{m}$ sieve to retain nematodes. Nematodes were collected in $10 \mathrm{ml}$ of water and aliquots of this suspension were used to identify all phytopathogenic nematodes by light microscopy. Lance nematodes were enumerated and classified into juvenile ( $\mathrm{J} 2$ or $\mathrm{J} 3+\mathrm{J} 4$ ) or adult life stage (male or female) by measuring body length and observing presence or absence of sexual morphological traits. Approximately $100 \mathrm{~g}$ of the remaining soil sample was used to calculate gravimetric soil moisture content ([fresh weight - dry weight $]$ /fresh weight) and nematode population densities were standardized by weight (per $100 \mathrm{~g}$ of dry soil).

Endoparasitic nematode populations were monitored monthly during July to October 2003 from the microplots and once during August 2003 from the putting green. For endoparasitic enumeration, a 4.5-by-10-cm core was collected. The top $1 \mathrm{~cm}$ of the core containing stolons and leaves was removed, and the remaining core was split into two lengthwise segments. Each segment was weighed, and half was retained for ectoparasitic extraction as previously mentioned. The remaining half was washed carefully in running tap water over a $355-\mu \mathrm{m}$ sieve to retain all roots. Roots of one segment were placed in a $125-$ or $250-\mathrm{ml}$ flask filled with water and aerated for 1 week. Aeration was ac- 
complished by directing pressurized air to the bottom of each flask via aquarium tubing to maintain a slow bubble. Water was added to flasks to compensate for evaporation as needed. H. galeatus endoparasites were collected by pouring the water over two nested sieves $(600-$ or $355-\mu \mathrm{m}$ mesh to capture the roots and a $25-\mu \mathrm{m}$ mesh to capture nematodes). Roots were dried at $45^{\circ} \mathrm{C}$ for 1 week and weighed.

Field plot sampling varied slightly from the microplots. Nematode populations were determined monthly (except January) by removing three 2 -by- $13.5-\mathrm{cm}$ soil cores from two subsamples from individual treatment plots. In 2000, the 24 plots measuring 2 by $8 \mathrm{~m}$ were divided in half, giving a total of 48 sample sites, each representing a 2-by-4-m area. During 2001 to 2002, the additional irrigation treatment doubled the number of plots to 48. Again, individual 1-by-8-m plots were divided in half, giving a total of 96 sample sites, each representing a 1-by-4-m area. The location for each subsample was systematically rotated monthly among four quadrants within each sampling site to reduce chances of resampling areas where cores had been removed.

The low clipping (3.2-mm) and daily irrigation treatments were terminated in
October 2002, but otherwise plots in 2003 were maintained as described previously. Analyses of variance of data were performed with the PROC GLM and MIXED procedures (44). Means were separated using Fisher's protected least significant difference test $(P<0.05$ unless otherwise stated). In some cases, seasonal $H$. galeatus population densities were summarized using an area under the curve (AUC) formula, where $\mathrm{AUC}=([$ average $H$. galeatus populations in June + July $] / 2)+([H$. galeatus number in July + August $] / 2)+$ ([H. galeatus number in August + September]/2) $(23,53)$. Surface maps of spatially aggregated $H$. galeatus populations across the research putting green were created by Kriging using Surfer 8 (Golden Software Inc., Golden, $\mathrm{CO}$ ).

\section{RESULTS}

Adult $H$. galeatus populations in a creeping bentgrass putting green fluctuated during summer, peaked in early October in 2000 and early August in 2001 and 2002, and then declined rapidly during the latter part of the month (Fig. 1). Population densities rebounded in fall but then decreased by approximately $50 \%$ through winter into April.

Seasonal fluctuations in $H$. galeatus populations were not apparent in mi- croplots in 2000 or 2001 (Fig 2). By 2002, $H$. galeatus at the $1 / 2 \times$ and $1 \times$ inoculum rates had a seasonal development similar to that of the naturally infested putting green field plots, except that populations peaked in early July. In 2003, H. galeatus population densities increased from June through August and then declined slightly during September.

Initial $H$. galeatus inoculum levels in microplots influenced nematode populations (Figs. 2 and 3 ). The $2 \times$ inoculum rate resulted in the highest average populations (AUC values) in 2000 and 2001. In 2002, AUC values for the three inoculum levels were similar and, by 2003 , population densities had reversed, with the highest $H$. galeatus numbers occurring in microplots originally inoculated at the $1 / 2 \times$ rate.

Ectoparasitic populations of $H$. galeatus in both the naturally and artificially infested plots were composed primarily of adults (Figs. 1 and 3). The ratios of female to male nematodes in the naturally infested plot were $32: 29,163: 113$, and 209:106 per $100 \mathrm{~g}$ of soil in 2000, 2001, and 2002, respectively (Fig. 2). Ratios of female to male nematodes in microplots increased from approximately $1: 1$ in 2000 (25:25 per $100 \mathrm{~g}$ of soil) to $2: 1$ (336:191 and 295:146 per $100 \mathrm{~g}$ of soil) in 2003 and 2004. Juve-

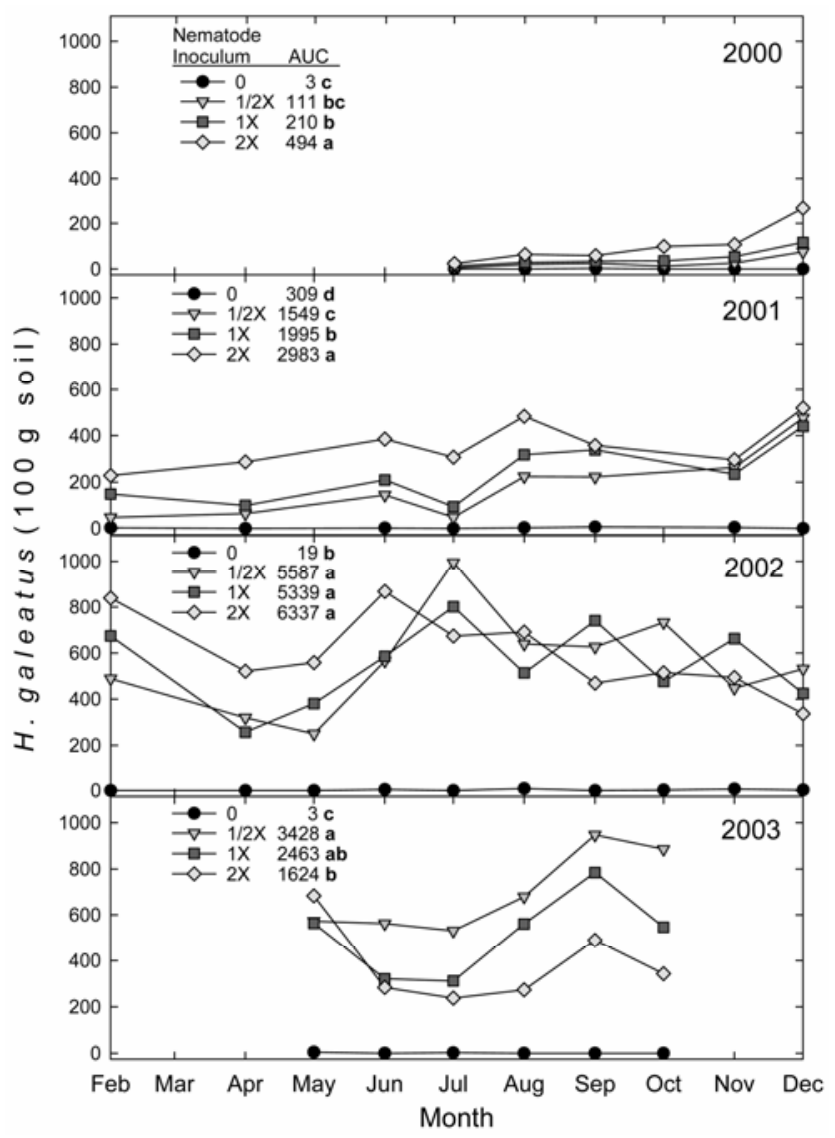

Fig. 2. Monthly Hoplolaimus galeatus populations in A-4 creeping bentgrass microplots at four initial inoculum levels. Area under the curve (AUC) values not followed by the same letter are significantly different according to Fisher's least significant difference comparison of leastsquares means $(P \leq 0.05)$.

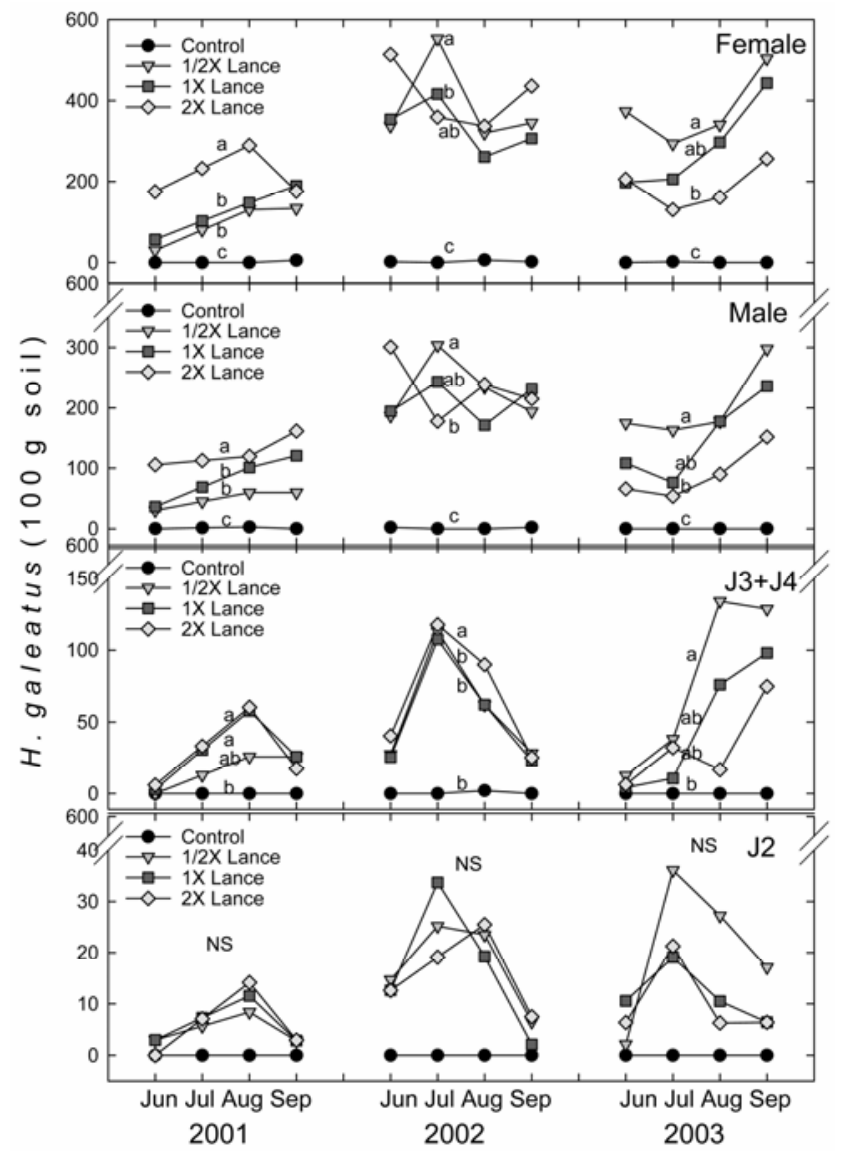

Fig. 3. Monthly adult (male and female) and juvenile Hoplolaimus galeatus populations in A-4 creeping bentgrass microplots at four initial inoculum levels. Area under the curve (AUC) values not followed by the same letter are significantly different according to Fisher's least significant difference comparison of least-squares means $(P \leq 0.05)$. 
nile numbers in the naturally infested plot were relatively low $(<100$ per $g$ of soil $)$ and constant in all months sampled except August 2002 (Fig. 1). Juveniles, averaged for all months, were $14 \%$ (4\% J2 and $10 \%$ $\mathrm{J} 3+\mathrm{J} 4)$ of the total nematode population in 2001 and $19 \%(4 \% \mathrm{~J} 2$ and $15 \% \mathrm{~J} 3+\mathrm{J} 4)$ in 2002.

Total endoparasitic populations of $H$. galeatus in the naturally infested putting green plots were similar to the ectoparasitic populations (341 versus 312 per $100 \mathrm{~g}$ of soil); however, the proportion of adults to juveniles differed, with juveniles composing $94 \%$ of all endoparasites (Fig. 4). We observed a similar population structure in microplots in July through October 2003 (Fig. 5).

Populations of $H$. galeatus were aggregated in the naturally infested plot (Fig. 6). In 2000, aggregates of high $H$. galeatus population densities were located near the center and northwestern edge of the plot, whereas nematodes were either at low densities or absent in southern quadrants. Populations in 2001 and 2002 tended to be uniformly higher but still spatially aggregated throughout the plot. Aggregates were not necessarily in the same location as the previous year.

There were no differences in $H$. galeatus populations among the four creeping bentgrass cultivars (Table 1). Similarly, irrigation regimes did not significantly alter total or adult $H$. galeatus ectoparasitic populations in either 2001 or 2002 (Table 1). Clipping height differentially influenced total ectoparasitic $H$. galeatus population densities among all cultivars except Penncross in 2002 but not in 2001 (Table 1; Fig 7). Compared with the 0.32-cm clipping height, average nematode populations in plots clipped at $0.4 \mathrm{~cm}$ were $25 \%$ higher in Crenshaw and 23\% higher in Providence in 2002. In contrast, nematode populations in L-93 were $25 \%$ higher at the $0.32-\mathrm{cm}$ clipping height. During peak juvenile $H$. galeatus populations in August 2002 (Fig. 1), similar clipping height effects occurred in Providence and L-93, but not Crenshaw (Table 1). Ectoparasitic juvenile populations were $42 \%$ greater at the 0.4-cm clipping height in Providence and $33 \%$ greater at the $0.32-\mathrm{cm}$ clipping height in L-93.

\section{DISCUSSION}

H. galeatus populations varied seasonally in naturally infested soil. In general, populations increased from late spring through midsummer, declined in August, and increased again in the fall. Chapman (8) reported that populations of $H$. galeatus on Kentucky bluegrass (Poa pratensis L.) were consistently lowest in August. Lucas et al. (31) reported similar population fluctuations of $H$. galeatus and stubby root (Paratrichodorus sp.) on creeping bentgrass in North Carolina. They concluded that the midsummer reduction in nematode populations followed a decline in turfgrass root health and biomass resulting from high soil temperatures. Soil temperatures exceeding $30^{\circ} \mathrm{C}$ result in creeping bentgrass root mortality $(3,26,27,38)$. Thus, increasing nematode populations in late spring and early summer probably are the result of a combination of favorable soil temperatures for nematode reproduction and optimal conditions for root growth (i.e., feeding sites), whereas late-summer decline is associated with root mortality and decreased root biomass associated with high temperatures. A similar phenomenon has been reported to occur on bermudagrass (Cynodon dactylon (L.) Pers.) putting greens in California infested with the sting nematode, Belonolaimus longicaudatus (4). This decline was thought to be caused by a reduced food supply.
$H$. galeatus populations in microplots did not exhibit the seasonal fluctuations in 2000 or 2001 that we observed in the naturally infested plots. This may be explained, in part, by the fact that $H$. galeatus population densities in the plots were relatively low in these years and less prone to fluctuations associated with seasonal changes in root biomass. Seasonal fluctuations were observed by the third year.

We observed a population increase and then a gradual decline in microplots inoculated with the highest level of $H$. galeatus, whereas populations at the lowest inoculum level continued to increase steadily. Density-dependent changes in nematode populations are commonly observed and, in this case, are likely the result of differential root damage from nematode feeding. Also, antagonistic soil microbial activity can contribute to population declines (10).

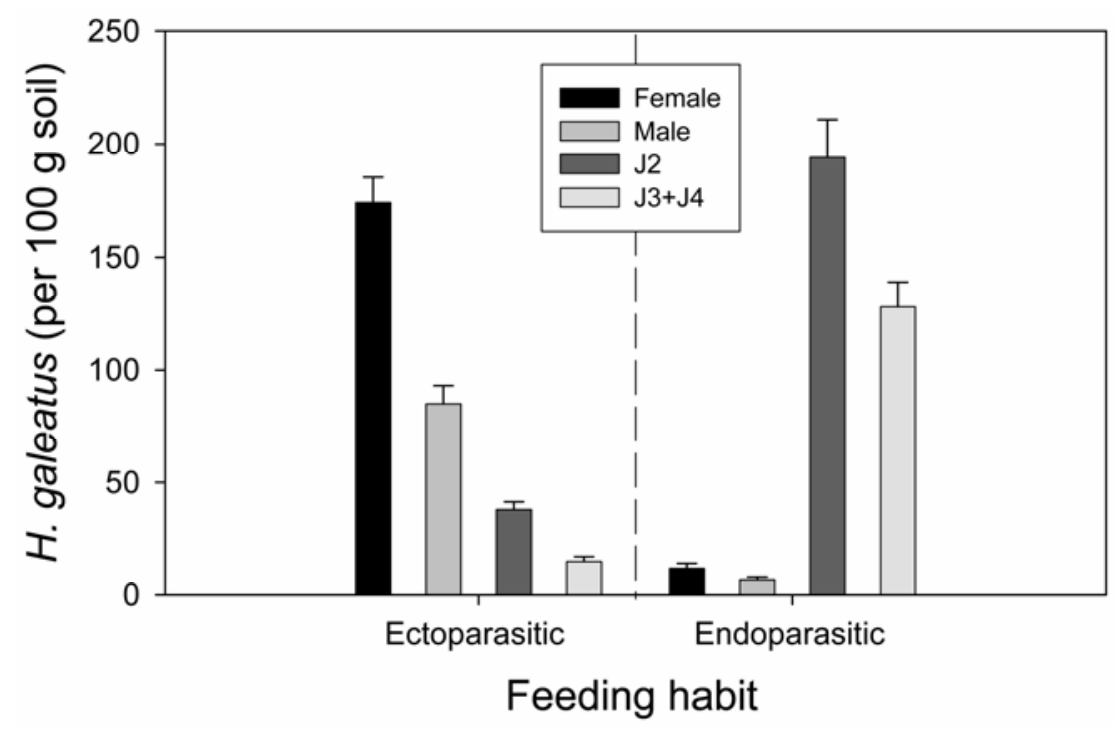

Fig. 4. Root feeding habit of Hoplolaimus galeatus in a creeping bentgrass putting green. Populations represent means of 96 samples collected in August 2003. Bars represent standard errors.

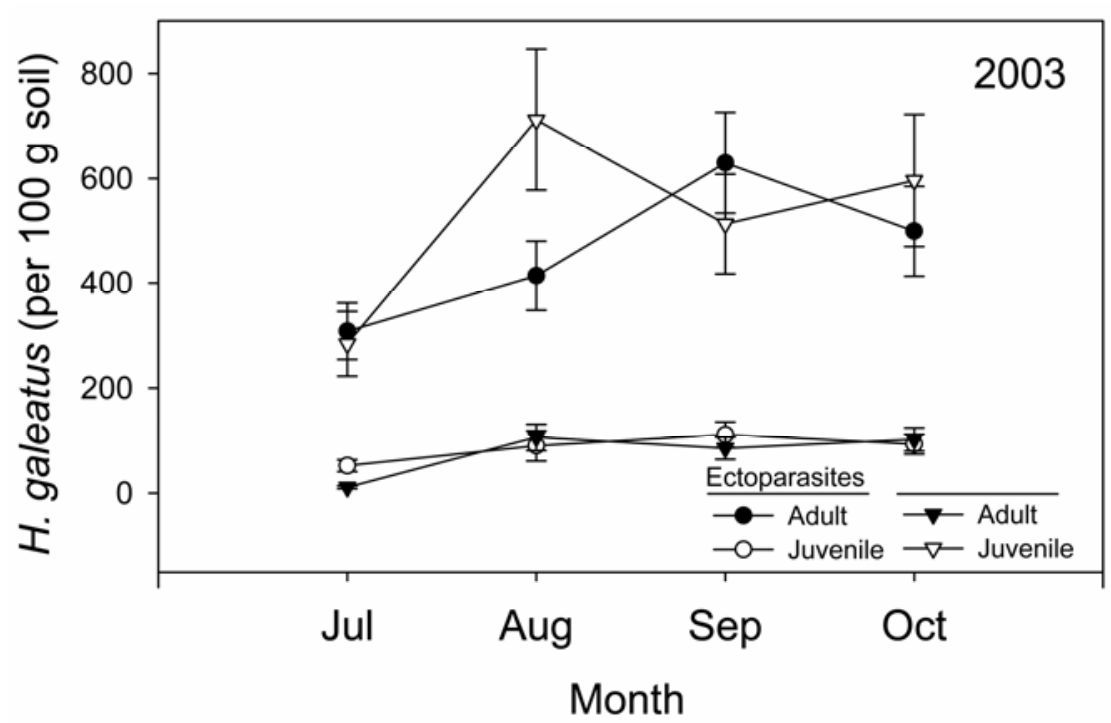

Fig. 5. Root feeding habit of Hoplolaimus galeatus in A-4 creeping bentgrass microplots. Monthly populations represent means of 16 microplots. Bars represent standard errors. 

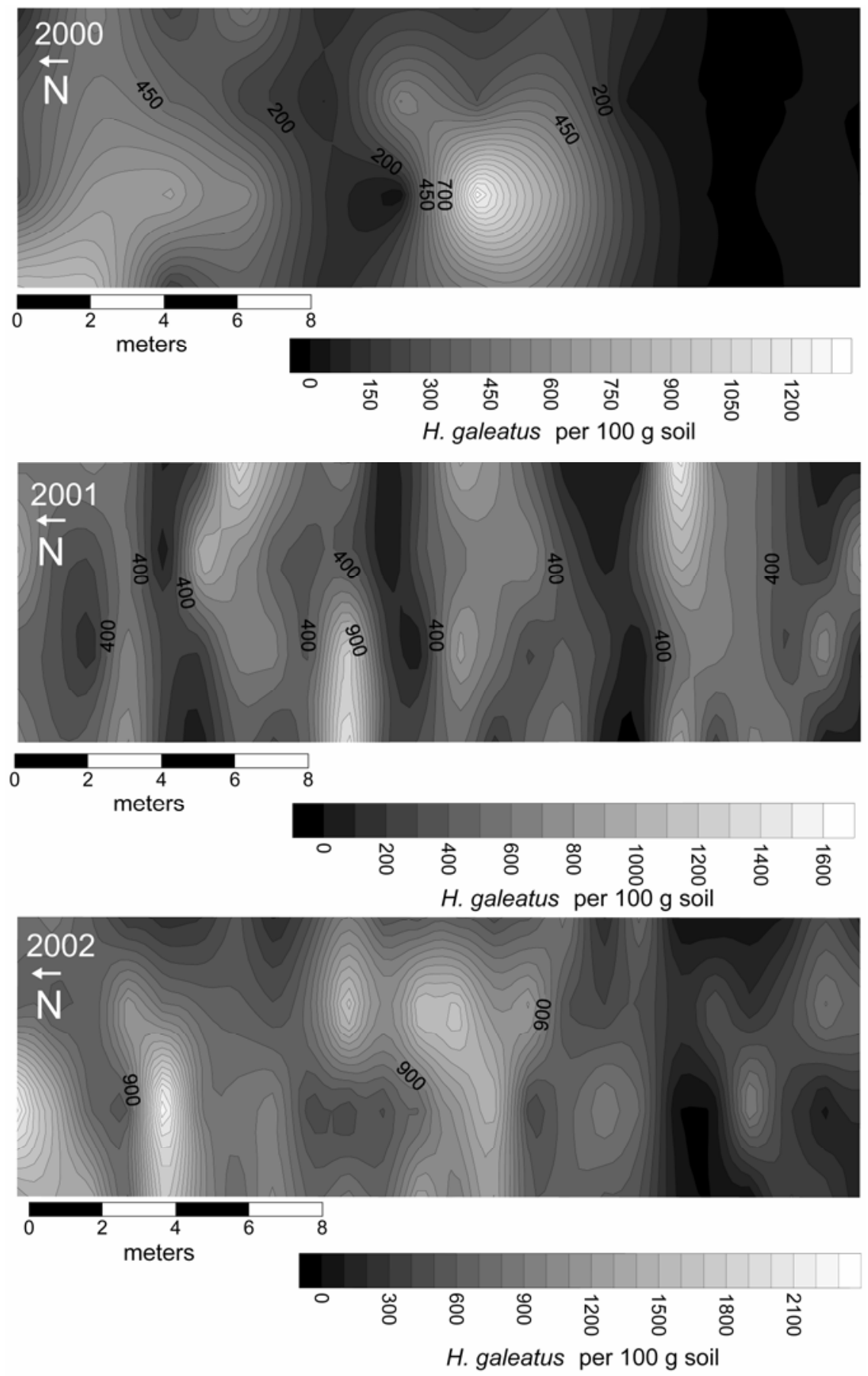

Fig. 6. Spatial distribution of Hoplolaimus galeatus in July 2000 and August 2001 and 2002 in a creeping bentgrass putting green.

For example, the antagonist Pasteuria penetrans is a common pathogen of $H$. galeatus $(12,20,36)$. However, we saw no evidence of Pasteuria spp. or other predators or pathogens during our sampling of the microplots.

Approximately half the $H$. galeatus populations in creeping bentgrass microplots were endoparasitic and, of those, over $90 \%$ were juveniles. Chapman (8) found that a majority of $H$. galeatus endoparasites were juveniles in Kentucky bluegrass. Giblin-Davis et al. (18) reported that 80 to $90 \%$ of H. galeatus in St. Augustinegrass were endoparasitic and that tions exceeding 2,000 per $100 \mathrm{~g}$ of soil in less than 2 years. Migration of nematodes to uninfested areas may occur with putting green management practices such as core aeration or via active migration of nematodes in soil. Although this might explain initial establishment, it does not fully elucidate the aggregated pattern. Other factors, including nematode interactions with the host, microbes, edaphic factors, and cultural practices, have been associated with spatial aggregation $(2,17,22,35,45)$.

$H$. galeatus populations were not influenced by bentgrass cultivar. The number of cultivars we tested was small, but the results suggest that differences among bentgrass genotypes to $H$. galeatus parasitism may be limited. H. galeatus feeds on a wide host range that includes both monocots and herbaceous and woody dicots $(1,11,39,41,42,47,52)$, and this may make finding differences in feeding preference among cultivars difficult.

We hypothesized that daily irrigation would increase soil moisture content and reduce nematode populations, but this was not the case. The irrigation regimes we employed were similar to those golf course superintendents would use, but they did not result in large differences in soil moisture content (data not shown) between treatments. Browning et al. (6) reported that $H$. galeatus populations were reduced by $93 \%$ in annual bluegrass or creeping bentgrass turf and soil cores saturated with water for 1 week in the greenhouse compared with cores held at $50 \%$ water holding capacity. However, they were unable to influence $H$. galeatus numbers in the field by daily flooding of turf for one month. We conclude that irrigation practices commonly employed on putting greens are unlikely to influence $H$. galeatus populations.

Giblin-Davis et al. (19) found that lowering the clipping height of fairwaymaintained 'Tifgreen' bermudagrass from 1.3 to $0.65 \mathrm{~cm}$ reduced $H$. galeatus populations, but only at lower soil depths. We also observed a slight reduction in $H$. galeatus populations in Providence and Crenshaw in 2002 but not 2001. Low clipping heights can reduce bentgrass root production, increase summer root mortality (30), reduce carbohydrate levels (34), and potentially decrease feeding sites for nematodes. However, aggressive management practices (aeration, fertilization, and optimal irrigation) used on putting greens may ameliorate the negative effects of low mowing on $H$. galeatus. $H$. galeatus populations were greater in L-93 plots at the low clipping height in 2002. At the higher clipping height, L-93 became puffy and was prone to mowing injury caused by excessive removal of green leaf area, and resulted in exposure of underlying stolons. This might have negatively impacted the bentgrass health and resulted in a decrease in H. galeatus populations. 
Table 1. Analysis of variance table of ectoparasitic populations of Hoplolaimus galeatus in a naturally infested creeping bentgrass putting green as affected by cultivar, clipping height, and irrigation regime

\begin{tabular}{|c|c|c|c|c|c|c|}
\hline \multirow[b]{3}{*}{ Variable } & \multicolumn{6}{|c|}{$F$ value (ectoparasitic populations) ${ }^{\mathbf{a}}$} \\
\hline & \multicolumn{3}{|c|}{2001} & \multicolumn{3}{|c|}{2002} \\
\hline & Lance total & Adult & Juvenile & Lance total & Adult & Juvenile \\
\hline Month (MO) & 3.15 & 3.51 & 3.25 & $5.80 *$ & 3.70 & $8.47 *$ \\
\hline Bentgrass cultivar (CV) & 1.62 & 1.80 & 1.47 & 0.62 & 0.91 & 0.48 \\
\hline $\mathrm{MO} \times \mathrm{CV}$ & 2.44 & $2.99 *$ & 0.71 & 0.91 & 0.65 & 0.98 \\
\hline Irrigation (IRR) & 0.89 & 0.48 & 11.55 & 0.65 & 0.28 & 1.92 \\
\hline $\mathrm{MO} \times \mathrm{IRR}$ & 1.18 & 2.05 & 2.55 & 2.94 & 2.02 & 4.02 \\
\hline $\mathrm{CV} \times \mathrm{IRR}$ & 0.43 & 0.46 & 1.68 & 0.86 & 0.63 & 1.38 \\
\hline $\mathrm{MO} \times \mathrm{CV} \times \mathrm{IRR}$ & 0.67 & 0.59 & 0.72 & 0.76 & 0.68 & 1.42 \\
\hline Height (HT) & 2.18 & 2.24 & 0.40 & 0.88 & 1.36 & 0.00 \\
\hline $\mathrm{MO} \times \mathrm{HT}$ & 2.12 & 2.24 & 0.15 & 0.52 & 0.64 & 0.30 \\
\hline $\mathrm{CV} \times \mathrm{HT}$ & 2.58 & 2.78 & 1.42 & $5.01 *$ & $4.07 *$ & 2.58 \\
\hline $\mathrm{MO} \times \mathrm{CV} \times \mathrm{HT}$ & 0.85 & 1.00 & 0.52 & 1.38 & 1.43 & $2.32 *$ \\
\hline $\mathrm{IRR} \times \mathrm{HT}$ & 0.01 & 0.08 & 0.90 & 0.32 & 0.07 & 0.93 \\
\hline $\mathrm{MO} \times \mathrm{IRR} \times \mathrm{HT}$ & 0.29 & 0.31 & 0.80 & 1.11 & 1.15 & 0.52 \\
\hline $\mathrm{CV} \times \mathrm{IRR} \times \mathrm{HT}$ & 1.24 & 1.35 & 1.04 & 0.55 & 0.29 & 0.81 \\
\hline $\mathrm{MO} \times \mathrm{CV} \times \mathrm{IRR} \times \mathrm{HT}$ & 0.98 & 1.05 & 0.49 & 0.71 & 0.65 & 1.47 \\
\hline
\end{tabular}

a Asterisks * and $* *$ indicate $P \leq 0.05$ and 0.01 , respectively.

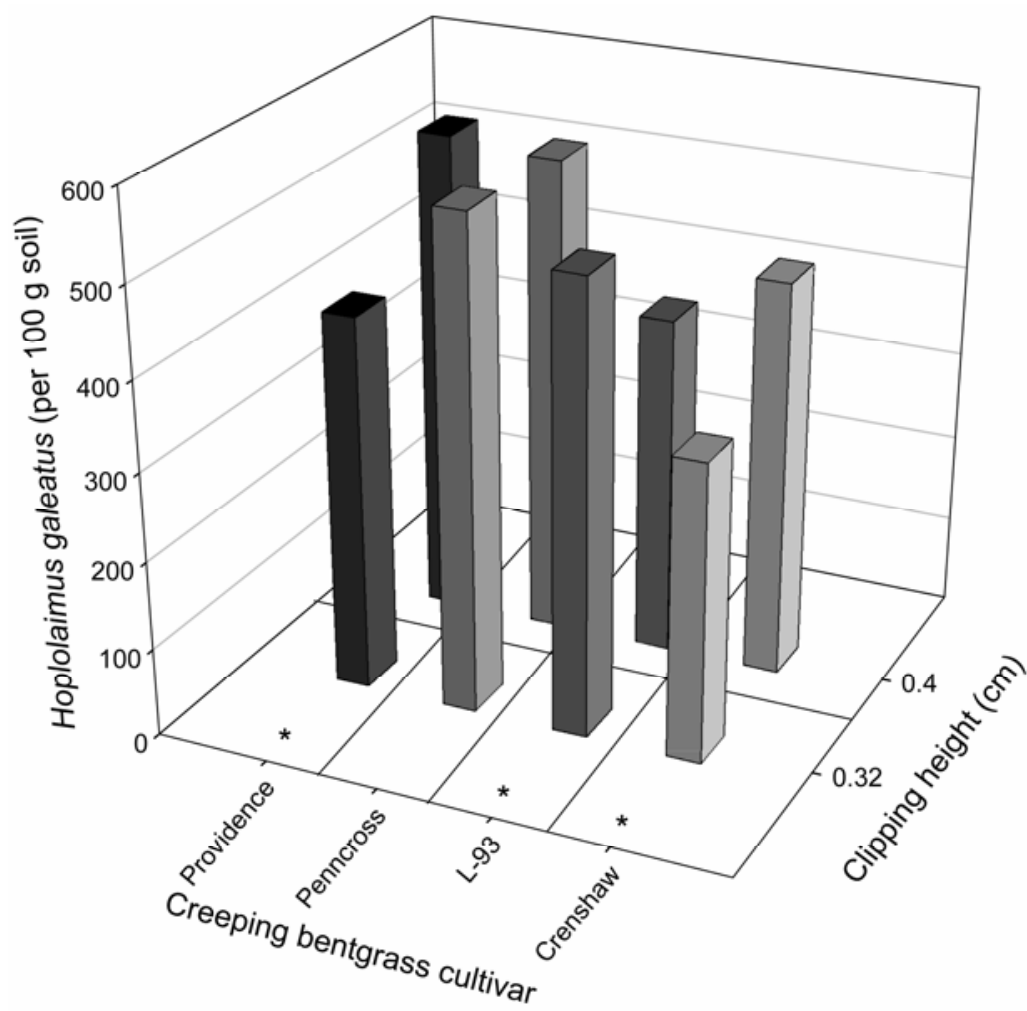

Fig. 7. Effect of clipping height on total (adult + juvenile) Hoplolaimus galeatus populations in four creeping bentgrass cultivars during summer (June to September) 2002. Cultivars with an asterisk indicate clipping heights are significantly different according to Fisher's least significant difference comparison of least-squares means $(P \leq 0.05)$.

In summary, we observed dynamic temporal and spatial fluctuations in $H$. galeatus populations in creeping bentgrass. In general, early July is the best time to estimate ectoparasitic $H$. galeatus numbers; however, care must be taken in interpreting results based on bulked soil samples from individual greens because of the aggregated nature of the nematode population.

\section{ACKNOWLEDGMENTS}

This research was sponsored by the Kansas Turfgrass Foundation.

\section{LITERATURE CITED}

1. Ahmad, M., and Chen, T. A. 1980. Effect of certain environmental factors and host plants on reproduction of Hoplolaimus galeatus. Plant Dis. 64:479-480.

2. Alby, T., Ferris, J. M., and Ferris, V. R. 1983. Dispersion and distribution of Pratylechus scriberi and Hoplolaimus galeatus in soybean fields. J. Nematol. 15:418-426.

3. Beard, J. B., and Daniel, W. H. 1965. Effect of temperature and cutting on the growth of creeping bentgrass (Agrostis palustris Huds.) roots. Agron. J. 5:249-250.

4. Bekal, S., and Ole Becker, J. 2000. Population dynamics of the sting nematode in California turfgrass. Plant Dis. 84:1081-1084.
5. Blackburn, K., Alm, S. R., Yeh, T. S., and Dawson, C. G. 1997. High-pressure liquid injection of isazofos for management of Hoplolaimus galeatus and Tylenchorhynchus dubius infesting turfgrasses. J. Nematol. 29:690-694.

6. Browning, M., Dawson, C., Alm, S. R., McElderry, C. F., and Amador, J. A. 1999. Effect of carbon amendment and soil moisture on Tylenchorhynchus spp. and Hoplolaimus galeatus. J. Nematol. 31:445-454.

7. Busey, P., Giblin-Davis, R. M., Riger, C. W., and Zaenker, E. I. 1991. Susceptibility of diploid St. Augustinegrasses to Belonolaimus longicaudatus. J. Nematol. 23:604-610.

8. Chapman, R. A. 1976. Population dynamics of Hoplolaimus galeatus in sod. J. Nematol. $8: 282$.

9. Chastagner, G. A., and McElroy, F. D. 1984. Distribution of plant-parasitic nematodes in putting green turfgrass in Washington. Plant Dis. 68:151-153.

10. Chavarria-Carvajal, J. A., Rodriguez-Kabana, R., Kloepper, J. W., and Morgan-Jones, G. 2001. Changes in populations of microorganisms associated with organic amendments and benzaldehyde to control plant-parasitic nematodes. Nematropica 31:165-180.

11. Churchill, R. C., Jr., and Ruehle, J. L. 1971. Occurrence, parasitism, and pathogenicity of nematodes associated with sycamore (Platanus occidentalis L.). J. Nematol. 3:189-196.

12. Ciancio, A., Vega Farfan, V., Carbonell Torres, E., and Grasso, G. 1998. Observations on a Pasteuria isolate parasitic on Hoplolaimus galeatus in Peru. J. Nematol. 30:206-210.

13. Davis, J. G., and Dernoeden, P. H. 2002. Dollar spot severity, tissue nitrogen, and soil microbial activity in bentgrass as influenced by nitrogen source. Crop Sci. 42:480-488.

14. Davis, R. F. 1994. Population fluctuations of three nematode genera in putting greens in northern Illinois. J. Nematol. 26:522-530.

15. Davis, R. F., Wilkinson, H. T., and Noel, G. R. 1994. Vertical distribution of three nematode genera in a bentgrass putting green in central Illinois. J. Nematol. 226:518-521.

16. Feldmesser, J., and Golden, A. M. 1972. Control of nematodes damaging home lawngrasses in two counties in Maryland. Plant Dis. Rep. 56:476-480.

17. Francl, L. J. 1993. Multivariate analysis of selected edaphic factors and their relationship to Heterodera glycines population density. J. Nematol. 25:270-276.

18. Giblin-Davis, R., Busey, P., and Center, B. 1995. Parasitism of Hoplolaimus galeatus on 
diploid and polyploid St. Augustinegrasses. J. Nematol. 27:472-477.

19. Giblin-Davis, R. M., Cisar, J. L, Bilz, F. G., and Williams, K. E. 1991. Management practices affecting phytoparasitic nematodes in 'Tiffgreen' bermudagrass. Nematropica 21:5969.

20. Giblin-Davis, R. M., McDaniel, L.L., and Bilz, F. G. 1990. Isolates of the Pasteuria penetrans group from phytoparasitic nematodes in bermudagrass turf. Suppl. J. Nematol. 22:750762

21. Good, J. M., Steele, A. E., and Ratcliffe, T. J. 1959. Occurrence of plant parasitic nematodes in Georgia turf nurseries. Plant Dis. Rep. 3:236-238

22. Goodell, P., and Ferris, H. 1980. Plantparasitic nematode distributions in an alfalfa field. J. Nematol. 12:136-141.

23. Guan, J., and Nutter, F. W., Jr. 2002. Relationships between percentage defoliation, dry weight, percentage reflectance, leaf-to-stem ratio, and green leaf area index in the alfalfa leaf spot pathosystem. Crop Sci. 42:1264-1273.

24. Heald, C. M., and Burton, G. W. 1968. Effect of organic and inorganic nitrogen on nematode populations on turf. Plant Dis. Rep. 52:46-48.

25. Hoveland, C. S., Rodriguez-Kabana, R., and Berry, C. D. 1975. Phalaris and tall fescue forage production as affected by nematodes in the field. Agron. J. 67:714-717.

26. Huang, B., and Liu, X. 2003. Summer root decline: production and mortality for four cultivars of creeping bentgrass. Crop Sci. 43:258265.

27. Huang, B., Liu, X., and Fry, J. D. 1998. Effects of high temperature and poor soil aeration on root growth and viability of creeping bentgrass. Crop Sci. 38:1618-1622.

28. Jenkins, W. 1964. A rapid centrifugal-flotation technique for separating nematodes from soil. Plant Dis. Rep. 48:692.

29. Lewis, S. A., and Fassuliotis, G. 1982. Lance nematodes, Hoplolaimus spp., in the southern United States. Pages 127-138 in: Nematology in the Southern Region of the United States. R. D. Riggs, ed. South. Coop. Ser. Bull. 276. Arkansas Agricultural Experiment Station, Fayetteville.

30. Liu, X., and Huang, B. 2002. Mowing effects on root production, growth, and mortality of creeping bentgrass. Crop Sci. 42:1241-1250.

31. Lucas, L. T., Barker, K. R., and Blake, C. T. 1978. Seasonal changes in nematode densities on bentgrass golf greens in North Carolina. Plant Dis. Rep. 62:373-376.

32. Murdoch, C. L., Tashiro, H., and Harrison, M. B. 1978. Plant-parasitic nematodes associated with golf putting-green turf in New York. Plant Dis. Rep. 62:85-87.

33. Myers, R. F., Wagner, R. E., and Halisky, P. M. 1992. Relationship between cultural factors and nematodes on Merion Kentucky bluegrass. J. Nematol. 24:205-211.

34. Narra, S., Fermanian, T. W., Swiader, J. M., Voigt, T. B., and Branham, B. E. 2004. Total nonstructural carbohydrate assessment in creeping bentgrass at different mowing heights. Crop Sci. 44:908-913.

35. Noe, J. P., and Campbell, C. L. 1985. Spatial pattern analysis of plant-parasitic nematodes. J. Nematol. 17:86-92.

36. Oostendorp, M., Hewlett, T. E., Dickson, D. W., and Mitchell, D. J. 1991. Specific gravity of spores of Pasteuria penetrans and extraction of spore-filled nematodes from soil. Supplement to J. Nematol. 23:729-732.

37. Radewald, J. D., Pyeatt, L., Shibuya, F., and Humphrey, W. 1970. Meloidogyne naasi, a parasite of turfgrass in Southern California. Plant Dis. Rep. 54:940-942.

38. Ralston, D. S., and Daniel, W. H. 1972. Effect of temperatures and water table depth on the growth of creeping bentgrass roots. Agron. J. 64:709-713.

39. Rhoades, H. L. 1987. Effects of Hoplolaimus galeatus on ten vegetable crops in Florida. Nematropica 17:213-218.

40. Rodriguez-Kabana, R. 1986. Organic and inorganic nitrogen amendments to soil as nematode suppressants. J. Nematol. 18:129135.

41. Ruehle, J. L. 1970. Nematodes parasitic on forest trees: III. Reproduction on selected hardwoods. J. Nematol. 3:170-173.

42. Ruehle, J. L. 1973. Influence of plant-parasitic nematodes on longleaf pine seedlings. J. Nematol. 5:7-9.

43. Safford, J., and Riedel, R. M. 1976. Criconemoides species associated with golf course turf in Ohio. Plant Dis. Rep. 60:405408
44. SAS Institute. 1989. SAS/STAT User's Guide, 4th ed. Version 6. SAS Institute, Inc., Cary, NC.

45. Seinhorst, J. W. 1982. The distribution of cysts of Globodera rostochiensis in small plots and the resulting sampling errors. Nematologica 28:285-297.

46. Sumner, D. R. 1967. Nematodes in bluegrass. Plant Dis. Rep. 51:457-460.

47. Tarjan, A. C. 1951. Observations on nematodes associated with decline of ornamental plantings. Plant Dis. Rep. 35:217-218.

48. Tashiro, H., Murdoch, C. L., and Apt, W. J. 1977. Plant-parasitic nematodes associated with golf course putting green turf Hawaii. Plant Dis. Rep. 61:919-921.

49. Taylor, D. P., Britton, M. P., and Hechler, H. C. 1963. Occurrence of plant parasitic nematodes in Illinois golf greens. Plant Dis. Rep. 47:134135.

50. Todd, T. C., and Tisserat, N. A. 1990. Occurrence, spatial distribution, and pathogenicity of some phytoparasitic nematodes on creeping bentgrass putting greens in Kansas. Plant Dis. 74:660-663.

51. Troll, J., and Tarjan, A. C. 1954. Widespread occurrence of root parasitic nematodes in golf course greens in Rhode Island. Plant Dis. Rep. 38:342-344

52. Viggars, R. M., and Tarjan, A. C. 1949. A new root disease of pin oaks possibly caused by the nematode, Hoplolaimus coronatus Cobb. Plant Dis. Rep. 33:132-133.

53. Waggoner, P. E. 1981. Progress curves of foliar diseases: their interpretation and use. Pages 3 37 in: Plant Disease Epidemiology. Vol. 1. Population Dynamics and Management. K. J. Leonard and W. E. Fry, eds. Macmillan Publishing, New York.

54. Walker, N. A., and Martin, D. L. 2001. Effects of Tylenchoryhnchus claytoni on creeping bentgrass. (Abstr.) Phytopathology 91:S93.

55. Walker, N. R., Doad, C. L., Zhang, H., and Martin, D. L. 2002. Factors associated with populations of plant-parasitic nematodes in bentgrass putting greens in Oklahoma. Plant Dis. 86:764-768.

56. Wick, R. L., and Vittum, P. J. 1988. Spatial and temporal distribution of plant parasitic nematodes in putting greens in the New England region. (Abstr.) Phytopathology 78:1521. 